\title{
PENGEMBANGAN PERANGKAT PEMBELAJARAN BERBASIS MASALAH (PROBLEM BASED LEARNING) PADA MATERI MATRIKS UNTUK KELAS X SMK SAMARINDA
}

\author{
Ikmawati $^{1)}$ \\ Alfiah Nur Badariyah \\ ${ }^{1)}$ Dosen Pendidikan Matematika FKIP Universitas Mulawarman \\ Email: ${ }^{1)}$ watiyusuf123@gmail.com
}

\begin{abstract}
ABSTRAK
Penelitian ini bertujuan untuk menghasilkan perangkat pembelajaran berbasis masalah yang baik dan mendeskripsikan keefektifan pembelajaran berbasis masalah yang baik pada materi Matriks untuk kelas X SMK Samarinda. Penelitian pengembangan ini mengikuti rancangan 4-D model dari Thiagarajan (1974) sampai pada tahap 3-D saja yaitu: tahap pendefinisian, tahap perancangan, dan tahap pengembangan perangkat. Perangkat pembelajaran yang dikembangkan adalah Rencana Pelaksanaan Pembelajaran (RPP), Lembar Kerja Siswa (LKS), Tes Hasil Belajar (THB). Instrument yang digunakan dalam penelitian ini, yaitu lembar validasi perangkat pembelajaran, lembar pengamatan aktivitas siswa, lembar pengamatan kemampuan guru mengelola pembelajaran, dan angket respon siswa. Kelas uji coba dilakukan di kelas X-D Farmasi SMK Farmasi Samarinda diperoleh hasil perangkat yang terdiri dari: Perangkat pembelajaran dikatakan valid oleh validator, kemampuan guru mengelola pembelajaran baik rata-rata (4.52), aktivitas siswa baik, respon siswa terhadap pembelajaran positif, tes hasil belajar valid, reliabilitas sedang (0.59), dan sensitif butir soal antara 0 dan 1, penilaian sikap baik. Untuk kelas uji keefektifan dilaksanakan di kelas X-MM SMK TI Pratama Samarinda yang sudah memenuhi syarat keefektifan yaitu: ketuntasan belajar secara klasikal terpenuhi (85\%), aktivitas siswa baik, respon siswa terhadap pembelajaran positif, dan kemampuan guru memenuhi kriteria baik rata-rata (4.28).
\end{abstract}

Kata kunci: Perangkat Pembelajaran, Problem Based Learning

\begin{abstract}
This study aims to produce a good problem-based learning tool and describe the effectiveness of problem-based learning is good on Matrix material for class X SMK Samarinda. This development study follows the design of 4-D model from Thiagarajan (1974) to 3-D stage only: defining phase, design stage, and device development stage. Learning tools developed are Learning Implementation Plan (RPP), Student Worksheet (LKS), Test Results Learning (THB). Instrument used in this research, namely learning device validation sheet, student activity observation sheet, teacher's ability observation sheet to manage learning, and student response questionnaire.The experimental class is conducted in class X-D of Pharmacy SMK Pharmacy Samarinda obtained result of device consist of: Learning device is valid by validator, ability of teacher to manage learning good average
\end{abstract}


(4.52), student activity good, student response to positive learning, test result learn valid, moderate reliability (0.59), and sensitive items between 0 and 1 , good attitude assessment. For class of effectiveness test is done in X-MM class of SMK TI Pratama Samarinda which have fulfilled the effectiveness requirement that is: learning completeness classically fulfilled (85\%), good student activity, student's response to positive learning, and ability of teacher fulfill criteria good average (4.28).

Keywords: Learning Tool, Problem Based Learning

\section{PENDAHULUAN}

Matematika adalah mata pelajaran yang sangat penting bagi siswa. Oleh karena itu matematika diajarkan pada setiap jenis dan jenjang pendidikan, mulai dari pendidikan dasar sampai pada pendidikan tinggi, baik pendidikan umum maupun kejuruan. Pada penelitian ini akan dilaksanakan dijenjang SMK, karena peneliti pernah mengajar di jenjang SMK banyak menjumpai siswa yang mengeluh kesulitan dalam belajar matematika, sehingga banyak siswa yang tidak menyenangi mata pelajaran matematika.

Salah satu penyebab kesulitan siswa dalam mempelajari matematika adalah proses pembelajaran guru yang kurang mengoptimalkan peran siswa. Dari analisis hasil penelitian internasional pendidikan matematika yang dilakukan oleh Setiawati (2013) proses pembelajaran matematika di Indonesia masih merupakan suatu proses pembelajaran di mana guru hanya memberikan pengetahuan hafalan, dan kurang menekankan pada aspek kognitif.

Kesulitan yang dialami siswa dalam belajar matematika yaitu kurangnya pemahaman siswa terhadap apa yang mereka pelajari itu antara lain disebabkan oleh matematika adalah konsep yang abstrak. Hudojo (2005) menjelaskan hakekat matematika adalah ilmu pengetahuan yang berkenaan dengan ide-ide, struktur-struktur, dan hubungan-hubungan yang diatur menurut aturan yang logis dan berkenaan dengan konsep-konsep yang abstrak.

Salah satu hal yang harus dipikirkan dan dilaksanakan oleh guru saat ini adalah melibatkan siswa dalam pembelajaran matematika dengan cara siswa berpartisipasi aktif dalam setiap pembelajaran sehingga pelajaran matematika menjadi pelajaran yang mudah dan menyenangkan. PBL (Problem Based Learning) dapat menjadi salah satu alternatif model pembelajaran yang dapat membuat siswa menjadi aktif dalam proses pembelajaran. Menurut Arrends (2012), PBL merupakan suatu model pembelajaran dimana siswa mengerjakan permasalahan yang autentik yaitu suatu permasalahan yang dialami siswa dalam kehidupan sehari-hari dengan maksud untuk menyusun pengetahuan mereka sendiri, mengembangkan inkuiri dan meningkatkan kemampuan tingkat tinggi dan melatih kemandirian siswa.

Pembelajaran berbasis masalah merupakan suatu model pembelajaran dimana siswa diajak untuk menyelesaikan masalah dengan maksud membangun pengetahuan mereka sendiri, sehingga dalam penggunaan model pembelajaran tersebut diperlukan perangkat pembelajaran yang baik dan efektif dalam pembelajaran. Perangkat 
pembelajaran tersebut adalah Rencana Pelaksanan Pembelajaran (RPP), Lembar kegiatan siswa (LKS), lembar penilaian berupa Tes Hasil Belajar (THB) dan lembar pengamatan.

Dalam penelitian ini peneliti mengembangkan perangkat pembelajaran untuk materi matriks karena merupakan salah satu materi yang dapat diajarkan dengan pembelajaran berbasis masalah. Pada materi matriks banyak yang berkaitan dengan masalah sehari-hari siswa. Berbasis latar belakang yang telah dikemukakan di atas, maka peneliti akan melakukan penelitian tentang Pengem-bangan Perangkat Pembelajaran Berbasis Masalah (Problem Based Learning) pada materi matriks untuk Kelas X SMK.

Adapun tujuan dari penelitian ini adalah menghasilkan perangkat pembelajaran berbasis masalah (problem based learning) pada materi matriks untuk kelas $\mathrm{X}$ SMK Samarinda. Mendeskripsikan keefektifan pembelajaran berbasis masa-lah (problem based learning) yang baik pada materi matriks untuk kelas X SMK Samarinda.

\section{METODE PENELITIAN}

Penelitian ini merupakan penelitian pengembangan, karena dalam penelitian ini mengembangkan perangkat pembe-lajaran dengan model PBL pada materi matriks. Hasil pengembangan perangkat berupa Rencana Pelaksanaan Pembe-lajaran (RPP), Lembar kegiatan siswa (LKS), dan Tes Hasil Belajar (THB).

Pelaksanaan uji coba pada penelitian ini dilakukan di kelas X-D Farmasi SMK Farmasi Samarinda dan kelas keefektifan dilaksanakan di kelas X-MM SMK TI Pratama tahun ajaran 2017/2018. Pe- milihan kelas ditentukan berbasis persetujuan guru mata pelajaran dan Kepala Sekolah. Berbasis informasi dari sekolah bahwa pembagian kelas secara umum dilakukan secara merata, artinya siswa yang memiliki kemampuan tinggi, sedang, dan rendah tersebar secara merata di setiap kelas di sekolah yang peneliti tempati.

Instrumen pengumpulan data uji coba perangkat pembelajaran, secara singkat diuraikan sebagai berikut (a) Lembar validasi perangkat pembelajaran; (b) Lembar pengamatan kemampuan guru mengelola pembelajaran; (c) Lembar observasi aktivitas siswa; (d) Lembar angket respons siswa; (e) Lembar Penilaian.

Sedangkan untuk lembar penga-matan digunakan untuk melihat sikap siswa selama proses pembelajaran, dalam penelitian ini yang akan diamati sikap: disiplin, bekerjasama dan toleran.

Untuk menganalisis data uji coba perangkat pembelajaran, data yang dianalisis adalah sebagai berikut.

a. Analisis data validasi perangkat pembelajaran

Validator menuliskan penilaian pada setiap lembar validasi perangkat pembelajaran pada materi sistem per-samaan linear dua variabel yang terdiri dari RPP, LKS, dan lembar penilaian yang terdiri dari THB dan lembar pengamatan. Pada RPP dan LKS penilaian terdiri dari 4 kategori yaitu: sangat tidak baik (nilai 1), tidak baik (nilai 2), baik (nilai 3), dan sangat baik (nilai 4). Perangkat pembe-lajaran (RPP dan LKS) dikatakan valid jika setiap komponen perangkat pembelajaran mendapat kategori minimal baik (nilai 3). Sedangkan pada THB validator membe- 
rikan penilaian aspek isi, bahasa, dan penulisan.

Pada validasi isi, validator memberikan penilaian berupa valid, cukup valid, kurang valid, dan tidak valid. Pada validasi bahasa validator memberikan penilaian berupa sangat dapat dipahami, dapat dipahami, kurang dapat dipahami dan tidak dapat dipahami. THB dikatakan valid jika validator memberikan penilaian isi pada kategori cukup valid atau valid, pada penilaian bahasa dan penulisan soal diisi kategori dapat dipahami atau sangat dipahami. Sedangkan pada lembar pengamatan digunakan layak atau tidak layak baik dari segi validitas isi maupun dari validitas konstruksi. Jika validator menyatakan layak maka lembar pengamatan tersebut baik untuk digunakan.

b. Analisis data kemampuan guru mengelola pembelajaran

Data kemampuan guru mengelola pembelajaran selama kegiatan pembelajaran berlangsung dianalisis dengan menggunakan skor rata-rata Tingkat Kemampuan Guru (TKG) sebagai berikut:

$1,00 \leq \mathrm{TKG}<1,50$ tidak baik

$1,50 \leq \mathrm{TKG}<2,50$ kurang baik

$2,50 \leq$ TKG $<3,50$ cukup

$3,50 \leq \mathrm{TKG}<4,50$ baik

$4,50 \leq$ TKG $<5,00$ baik sekali

Kemampuan guru mengelola pembelajaran dikatakan efektif jika skor dari setiap aspek yang dinilai berada pada kategori baik atau sangat baik. Dengan demikian hasil analisis data yang tidak memenuhi dari salah satu kategori baik atau sangat baik pada penelitian ini akan dijadikan bahan pertimbangan untuk merevisi perangkat pembelajaran yang telah diuji cobakan. c. Analisis data aktivitas siswa

Data hasil pengamatan aktivitas siswa selama kegiatan pembelajaran berlangsung dianalisis dengan menggunakan persentase.

d. Analisis data respons siswa

Data tentang respons siswa yang diperoleh melalui angket dianalisis dengan menggunakan statistik deskriptif dengan persentase. Respons siswa dikatakan positif jika jawaban siswa terhadap angket respons per-tanyaan positif untuk setiap aspek yang direspons pada setiap komponen pembelajaran diperoleh persentase $\geq 80 \%$. Sedangkan jika persentase yang diperoleh kurang dari $80 \%$, maka akan dipertimbangkan untuk merevisi perangkat pembelajaran.

e. Analisis tes hasil belajar

Tes hasil belajar disusun dengan berpedoman pada rumusan kom-petensi dasar pencapaian hasil belajar. Analisis butir tes meliputi uji validitas, uji sentivitas, dan uji reliabilitas.

1) Validitas

Tes memiliki validitas jika tes tersebut mampu mengukur apa yang seharusnya diukur.

2) Sensitivitas

Uukuran seberapa baik butir soal itu dapat membedakan tingkat kemampuan siswa sebelum dan sesudah menerima pembelajaran.

3) Reliabilitas

Tes mempunyai reliabilitas apabila telah memiliki daya keajengan untuk mengukur.

\section{Metode Pengembangan Perangkat Pem-} belajaran

Pada pengembangan perangkat pembelajaran penelitian ini menggunakan 3-D mengikuti tahap-tahap pengembangan model 4-D thiagarajan, sammel and sammel 
(1974) yaitu, pendefinisian (define), perencanaan (desain), pengembangan (develop). Sedangkan penyebaran (dissemination) tidak dilakukan karena terkendala waktu dan dana yang tersedia, selengkapnya tiga tahapan tersebut diuraikan sebagai berikut (1) Tahap pendefinisian (define) tahap ini bertujuan untuk menetapkan dan pendefinisian syarat-syarat yang dibutuhkan dalam pembelajaran. Kegiatan yang dilakukan pada tahap ini adalah analisis awalakhir, analisis siswa, analisis materi, analisis tugas, dan perumusan tujuan pembelajaran; (2) Tahap peran-cangan (desain) tujuan tahap ini adalah untuk menyiapkan materi pembelajaran. Tahap ini terdiri dari: (a) pemilihan me-dia, (b) pemilihan format, (c) perancangan awal perangkat pembelajaran; (3) Tahap pengembangan (develop) bertujuan untuk menghasilkan perangkat pembelajaran yang telah divalidasi berbasis masukan para ahli. Tahapan ini meliputi: (a) validasi ahli, (b) uji keterbacaan, (c) uji coba.

\section{HASIL PENELITIAN DAN PEMBA- HASAN}

Diperoleh hasil pengembangan perangkat pembelajaran yang baik menurut validator karena sudah meme-nuhi kriteria: valid, karena perangkat yang disusun sesuai dengan subjek disiplin ilmu yang sesuai (validitas isi) dan semua komponen dalam perangkat saling terhubung secara konsisten (validitas konstruk) itu dapat dilihat dari rata-rata penilaian validator terhadap perangkat pembelajaran yang disusun yaitu: RPP mempunyai rata-rata 3.41 , LKS ratarata 3.74 , THB rata-rata 3.18 , dan rata-rata LPPS 4.00. Praktis, karena menurut validator perangkat yang disusun dapat digunakan oleh guru dan siswa sesuai dengan keinginan dari pengembangan perangkat. Efektif, karena perangkat yang disusun valid menurut validator setelah divalidasi. Dimana secara umum hasil validasi para validator terhadap perangkat pembelajaran dapat disimpulkan sebagai berikut. Rencana Pelaksanaan Pembelajaran (RPP) mempunyai kategori valid dan dapat digunakan dengan sedikit revisi. Lembar Kegiatan Siswa (LKS) mempunyai kategori valid dan dapat digunakan dengan sedikit revisi. Tes Hasil Belajar (THB) mempunyai kategori valid dan dapat digunakan dengan sedikit revisi. Lembar Pengamatan Penilaian Sikap (LPPS) mempunyai kategori valid dan layak digunakan dengan sedikit revisi.

Data hasil belajar dianalisis untuk melihat validitas, sensitivitas dan reliabilitas instrumen tes hasil belajar. Perhitungan validitas, sensitivitas dan reliabilitas instrumen tes hasil belajar dapat dilihat pada lampiran.

\section{a. Validitas}

Hasil perhitungan validitas setiap butir tes dengan menggunakan rumus korelasi product moment disajikan pada tabel 1 .

Tabel 1. Validitas butir tes

\begin{tabular}{lcccc}
\hline No soal & 1 & 2 & 3 & 4 \\
\hline$r_{x y}$ & 0.47 & 0.43 & 0.46 & 0.80 \\
\hline
\end{tabular}

Kriteria Sedang Sedang Sedang Tinggi

Berdasarkan kriteria kelayakan butir tes, maka setiap butir tes dikategorikan valid dan layak digunakan dalam penelitian.

b. Reliabilitas

Berdasarkan hasil perhitungan reliabilitas tes (kelas uji coba) diperolah koefisien reliabilitas 0.59 . Ini berarti butir tes memenuhi memenuhi kriteria reliabel. 
c. Sensitivitas

Hasil perhitungan sensitivitas setiap butir disajikan dalam tabel 2 .

Tabel 2. Sensitivitas butir tes

\begin{tabular}{lllll}
\hline No soal & 1 & 2 & 3 & 4
\end{tabular}

\begin{tabular}{lllll}
\hline Sensitivitas & 0.52 & 0.56 & 0.58 & 0.39
\end{tabular}

Kriteria Peka Peka Peka Peka

Semua butir tes memenuhi kriteria sensitif sehingga layak digunakan dalam penelitian.

\section{Pencapaian Kriteria Perangkat Pem- belajaran di Kelas Uji Coba}

Pembelajaran berbasis masalah untuk materi matriks dinyatakan efektif, karena memenuhi kriteria sebagai berikut (a) ketuntasan belajar secara klasikal terpenuhi; (b) aktivitas siswa baik; (c) respons siswa positif; (d) kemampuan guru mengelola pembelajaran baik; (e) penilaian sikap baik.

Tabel 3. Pencapaian kriteria perangkat pembelajaran

\begin{tabular}{clc}
\hline No & Aspek & Keterangan \\
\hline 1 & Validasi ahli & Valid \\
\hline 2 & $\begin{array}{l}\text { Kemampuan } \\
\text { guru mengelola } \\
\text { pembelajaran }\end{array}$ & Baik \\
\hline 3 & Aktivitas siswa & Efektif \\
\hline 4 & Respons siswa & Positif \\
\hline 5 & Penilaian sikap & Baik \\
\hline 6 & THB & $\begin{array}{l}\text { Valid, reliabel dan } \\
\text { sensitif }\end{array}$ \\
\hline
\end{tabular}

\section{Keefektifan}

Uji keefektifan dilakukan untuk mendeskripsikan keefektifan model pembelajaran berbasis masalah (PBL) dalam pembelajaran matematika untuk materi matriks di kelas X SMK Farmasi Samarinda.

Seperti pada kelas uji coba, sebagian besar waktu siswa kelas uji keefektifan dipergunakan untuk menyelesaikan permasalahan yang ada dalam LKS yaitu sebanyak $40 \%$ dari keseluruhan waktu yang tersedia.

Dari kelas uji keefektifan diperoleh 22 siswa dari 27 siswa telah tuntas belajar atau $85 \%$ siswa telah tuntas belajar, sedangkan pada kelas uji coba diperoleh 26 siswa dari 29 siswa telah tuntas belajar atau 90\% siswa telah tuntas belajar.

Sehingga dapat dikatakan bahwa pembelajaran berbasis masalah dapat menuntaskan belajar secara klasikal. Selama proses pembelajaran berlangsung siswa selalu berdiskusi dalam kelompok untuk menyelesaikan permasalahan yang ada pada LKS, dan menyimpulkan suatu konsep. Siswa yang berkemampuan akademik tinggi membantu siswa yang berkemampuan rendah.

Berkaitan dengan respons siswa terhadap pelaksanaan pembelajaran berbasis masalah, hasil analisis menunjukkan lebih dari $80 \%$ dari 27 siswa memberikan respons yang positif. Hal ini pun sesuai dengan pendapat Nieveen (1999) bahwa pembelajaran dikatakan efektif apabila perangkat tersebut merefleksikan pengalaman siswa dan hasil belajar siswa yang diharapkan. Sebagaimana yang dikemuakan oleh Mustaji (2005) bahwa dengan PBL siswa dapat merasakan manfaat pembelajaran sebab masalahmasalah yang di selesaikan langsung dikaitkan dengan kehidupan nyata, hal ini dapat meningkatkan motivasi dan ketertarikan siswa terhadap bahan yang 
dipelajari. Hal ini dapat dilihat dari respons siswa yang antusias dalam proses pembelajaran sehingga program pembelajaran dan hasil yang diperoleh sesuai dengan apa yang dimaksud oleh pengembang perangkat.

Berdasarkan uraian di atas, pembelajaran matematika model berbasis masalah (PBL) baik untuk diterapkan dalam pembahasan materi matriks di kelas $\mathrm{X}$ SMK, karena siswa menjadi aktif.

Kemampuan guru mengelola pembelajaran pada tahap uji keefektifan menunjukkan bahwa rata-rata skor kemampuan guru mengelola pembelajaran untuk RPP pertemuan 1 rata-ratanya 4,28. Berdasarkan hasil tersebut maka kemampuan guru dalam mengelola pembelajaran dikategorikan baik dalam kegiatan pembelajaran. Seperti pada pengamatan kemampuan guru mengelola pembelajaran nomor 1d (kegiatan awal) pengamat memberikan nilai 4 (baik) dimana di awal pembelajaran guru menghubungkan pelajaran yang akan diajarkan dengan pelajaran sebelumnya.

Dalam pelaksanaan pembelajaran ini, guru dituntut aktif mengarahkan, mendorong, atau memancing siswa untuk memahami dan menyelesaikan masalah sesuai dengan kemampuan mereka sendiri. Sebagaimana yang dikemukan oleh Arends (2012) masalah yang diberikan oleh guru adalah masalah yang dapat meningkatkan kemampuan berpikir dan memecahkan masalah, serta membangkitkan motivasi belajar siswa. Guru mendatangi kelompokkelompok yang mengalami kesulitan, kemudian membimbing siswa dalam kelompok tersebut sehingga siswa mampu memahami, menyelesaikan dan menarik kesimpulan sendiri dari kategori ini guru memperoleh skor rata-rata 4.00.

\section{KESIMPULAN}

Berdasarkan hasil penelitian dapat disimpulkan bahwa:

1. Pengembangan perangkat pembelajaran berbasis masalah untuk materi matriks dengan menggunakan model pengembangan 4-D yaitu:

a. Tahap Pendefinisian (define) yaitu: analisis awal-akhir, analisis siswa, analisis materi, analisis tugas dan perumusan tujuan pembelajaran.

b. Tahap Perancangan (design) yaitu: pemilihan media, pemilihan format, dan hasil perancangan awal perangkat pembelajaran.

c. Tahap Pengembangan (develop) yaitu: validasi ahli, uji keterbacaan, dan uji coba perangkat pembelajaran.

d. Sedangkan tahap penyebaran (Dissemination) tidak dilakukan karena terkendala waktu dan dana yang tersedia.

2. Hasil pengembangan perangkat pembelajaran (meliputi RPP, LKS, THB dan LPPS) memenuhi kriteria perangkat yang baik. Hal ini ditunjukkan oleh:

a. Perangkat pembelajaran dikatakan baik oleh validator berdasarkan kriteria:

1) Valid, karena perangkat yang disusun sesuai dengan subjek disiplin ilmu yang sesuai dan semua komponen dalam perangkat saling terhubung secara konsisten itu dapat dilihat dari rata-rata penilaian validator terhadap perangkat pem- 
belajaran yang disusun yaitu: RPP mempunyai rata-rata 3.77 , LKS rata-rata 3.74 , THB ratarata 3.75 , dan rata-rata LPPS 4.57 .

2) Praktis, karena perangkat yang digunakan dilaksanakan dengan baik berdasarkan pembelajaran berbasis masalah. Hal ini bisa diketahui dari kemampuan guru dalam mengelola pembelajaran memenuhi kriteria baik $(3.50 \leq$ TKG < 4.50).

3) Efektif, karena perangkat yang disusun valid menurut validator setelah divalidasi valid dan dapat digunakan.

b. Kemampuan guru mengelola pembelajaran kriteria baik $(3.50 \leq \mathrm{TKG}$ $<4.50)$ karena rata-rata skor yang diperoleh guru pada RPP (4.52)

c. Aktivitas siswa baik terlihat dari semua aspek aktivitas pada RPP mencapai toleransi keefektifan karena berarada dalam rentang waktu ideal yang telah ditetapkan. Terutama untuk aspek mendiskusikan jawaban LKS dalam kelompok, rata-rata persentasinya adalah $23.75 \%$ dari keseluruhan waktu $100 \%$.

d. Respons siswa terhadap pembelajaran positif karena rata-rata semua aspek berada di atas $80 \%$ menurut kriteria yang telah ditetapkan.

e. Tes hasil belajar:

1) Valid, berdasarkan kriteria kelayakan butir tes karena ratarata soal memiliki kriteria validitas (sedang dan tinggi)
2) Reliabel, karena diperoleh hasil 0.59 termasuk koefisien reliabilitas tinggi $\left(0.60<\mathrm{r}_{11} \leq\right.$ 0.80).

3) Sensitif, karena rata-rata setiap butir soal indeks sensitivitasnya (0.39 sampai dengan 0.58 ) berada antara 0 dan 1.

f. Penilaian sikap baik yaitu rata-rata di atas 50\% untuk penilaian setiap sikap.

3. Berdasarkan hasil deskriptif, diperoleh bahwa pembelajaran berbasis masalah efektif untuk mengajarkan materi matriks. Hal ini dibuktikan dengan terpenuhinya syarat keefektifan pembelajaran, yaitu:

a. Ketuntasan belajar secara klasikal terpenuhi.

Dari data postes kelas uji keefektifan menunjukkan bahwa 22 siswa dari 27 siswa telah tuntas belajar atau $85 \%$ siswa telah tuntas belajar. Sehingga dapat dikatakan pembelajaran berbasis masalah dapat menun-taskan belajar secara klasikal.

b. Aktivitas siswa baik

Berdasarkan pengamatan hasil aktivitas siswa selama pembelajaran mencapai toleransi keefektifan, karena berada dalam rentang waktu ideal yang telah ditetapkan.

c. Respons siswa terhadap pembelajaran positif

Berdasarkan kesimpulan hasil angket respons siswa rata-rata setiap aspek lebih dari atau sama dengan 80\%, sehingga dapat disimpulkan bahwa respons siswa 
terhadap pembelajaran berbasis masalah adalah positif

d. Kemampuan guru mengelola pembelajaran.

Hasil analisis data kemampuan guru mengelola pembelajaran menunjukkan rata-rata skor untuk 1 kali pertemuan adalah 4.28. Nilai ini berdasarkan kriteria kemampuan guru mengelola pembelajaran sudah memenuhi kriteria baik $(3.50 \leq \mathrm{TKG}<4.50)$.

\section{DAFTAR PUSTAKA}

Arend, Richard I. (1997). Classroom InsTruction and Management. New York: Mc Graw Hill Companies. . (2012). Learning to Teach.

New York: Mc Graw Hill Companies.

Ari, R dan Indriyastuti. (2008). Perspektif Matematika 2 Untuk Kelas XI SMA dan MA IPA. Solo: Tiga Serangkai Pustaka Mandiri.

Arikunto, Suharsimi. (2012). Dasar-Dasar Evaluasi Pendidikan. Jakarta: Bumi Aksara.

Hudojo, Herman. (2001). Pengembangan Kurikulum dan Pembelajaran Matematika. Malang: Universitas Negeri Malang. (2005). Mengajar Belajar Matematika. Jakarta: Depdikbud, Dirjen Dikti, P2LPTK.

Kementrian Pendidikan dan Kebudayaan Republik Indonesia. (2013). Buku Gu- ru Matematika Kelas X. Jakarta: Politeknik Negeri Medika Kreatif.

Masriyah dan Sugiarso. (2005). Pembelajaran Berbasis Konstruktivistik. Surabaya: Unesa University Press.

Morrison, Gary R, Steven M. Kalman, Howard K dan Kemp, Jerrold E. (2011). Designing Effective Instruction Sixth Edition. John Wiley and Son, Inc: USA.

Nur, M. (2011). Model Pembelajaran Berbasis Masalah. Surabaya: Universitas Negeri Surabaya.

Purwanto. (2009). Evaluasi Hasil Belajar. Yogyakarta: Pustaka Pelajar.

Rusma. (2012). Model-Model Pembelajaran (Mengembangkan Professional Guru). Jakarta: Raja Grafindo Persada.

Sasmito dkk. (2012). Model-Model Pembelajaran Inovatif. Surabaya: Universitas Surabaya.

Sudijono, Anas. (2012). Pengantar Evaluasi Pendidikan. Jakarta: Raja Grafindo Persada.

Sudjana, N. (2012). Penilaian Hasil Proses Belajar Mengajar. Bandung: Remaja Rosdakarya.

Thiaggarajan, Sivasilim dan Dorothy, Semmel. (1974). Instructional Development for Training Teacher of Exeptional Children. Minnesota Indiana University.

Trianto. (2013). Mendesain Model Pembelajaran Inovatif-Progresif. Jakarta: Kencana Persada Media Group. 
| Jurnal PRIMATIKA, Volume 8, Nomor 1, Juni 2019

42 Pengembangan perangkat pembelajaran berbasis masalah

Ikmawati-Alfiah Nur Badariyah 